Gut, 1982, 23, 589-593

\title{
Total body water and total body potassium in patients with continent ileostomies
}

\author{
L O NILSSON, H ANDERSSON, I BOSAEUS, and H E MYRVOLD
}

From the Department of Surgery II and Department of Clinical Nutrition, Sahlgrenska sjukhuset, University of Göteborg, Göteborg, Sweden

SUMMARY Total body water and total body potassium were studied in 14 patients submitted to proctocolectomy six to 10 years after they had been provided with a continent ileostomy. Total body water was determined with an isotope dilution technique using tritiated water as a tracer. Total body potassium was determined by counting the gamma radiation from the naturally present nuclid ${ }^{40} \mathrm{~K}$ in a total body counter. The results were compared with 'normal values' predicted by multiple regression analysis of data from 476 healthy controls which had been published earlier from the same laboratory. The investigations showed no signs of water or potassium depletion in patients with continent ileostomies.

Patients with chronic colitis often show a rapid improvement in their general condition after proctocolectomy. The ileal discharge, which is at first very liquid and voluminous, is after 10 days reduced to that of a long-established ileostomy. ${ }^{1}$ The loss of colon is, however, inevitably followed by increased fluid and electrolyte losses even when normal ileostomy function is established. ${ }^{2}$ Studies of body composition indicate a reduction in total body water and in total exchangeable sodium in patients with conventional ileostomies. ${ }^{3} 4$ Total body potassium, which is a measure of the total body cell mass and consequently reflects the nutritional status of the body, has been shown to increase after proctocolectomy compared with the status before operation. ${ }^{4}$

In the continent ileostomy, introduced by Kock in 1969,5 the intestinal contents are stored in an intra-abdominal pouch, which is constructed from a $45 \mathrm{~cm}$ segment of the distal ileum. ${ }^{56}$ Recent studies have shown that there is an active net absorption of water, sodium, and chloride in the pouch. ${ }^{7}$ Measurements of the renal excretion of sodium and potassium have shown values which are compatible with those of patients with conventional ileostomies but seem to be in the lower range of those in normal subjects. $^{8}$

The aim of the present study was to investigate if total body water and total body potassium in patients with continent ileostomies differ from those of normal subjects.

Received for publication 19 October 1981

\section{Methods}

SUBJECTS

Fourteen patients, seven men and seven women, who had had a well-functioning continent ileostomy for six to 10 years (mean $7 \cdot 5$ years) were investigated (Table 1). Thirteen patients had been submitted to proctocolectomy because of ulcerative colitis and one because of polyposis of the colon (patient no. 14). The mean age was 43 years (range 22-58 years). All patients were in good general health and displayed no signs of malabsorption. No

Table 1 Clinical data of 14 patients with continent ileostomy

\begin{tabular}{|c|c|c|c|c|}
\hline $\begin{array}{l}\text { Patient } \\
\text { no. }\end{array}$ & Sex & $\begin{array}{l}\text { Age } \\
(y r)\end{array}$ & $\begin{array}{l}\text { Interval } \\
\text { since } \\
\text { operation } \\
(y r)\end{array}$ & $\begin{array}{l}\text { Ileal } \\
\text { resection } \\
(\mathrm{cm})\end{array}$ \\
\hline 1 & $\mathbf{F}$ & 28 & 6 & 4 \\
\hline 2 & $\mathbf{F}$ & 55 & 6 & 12 \\
\hline 3 & $\mathbf{M}$ & 48 & 8 & 7 \\
\hline 4 & $\mathbf{M}$ & 39 & 6 & 7 \\
\hline 5 & $\mathbf{F}$ & 55 & 9 & 8 \\
\hline 6 & $\mathbf{M}$ & 58 & 7 & 13 \\
\hline 7 & $\mathbf{F}$ & 34 & 8 & 5 \\
\hline 8 & $\mathbf{F}$ & 52 & 10 & 4 \\
\hline 9 & $\mathbf{M}$ & 40 & 7 & 4 \\
\hline 10 & $\mathbf{F}$ & 54 & 8 & 3 \\
\hline 11 & $\mathbf{M}$ & 43 & 6 & 5 \\
\hline 12 & $\mathbf{F}$ & 31 & 10 & 10 \\
\hline 13 & $\mathbf{M}$ & 41 & 7 & 15 \\
\hline 14 & $\mathbf{M}$ & 22 & 7 & 4 \\
\hline
\end{tabular}


patient had an ileal resection of more than $15 \mathrm{~cm}$.

Reference values were obtained from 476 healthy males and females, who were investigated in the same laboratory. ${ }^{9}$

\section{PROCEDURE}

Total body water (TBW)

This was determined with an isotope dilution technique using tritiated water (THO) as a tracer. The subjects were given by mouth $100 \mu \mathrm{Ci}(3 \mathrm{M} \mathrm{Bq})$ tritiated water diluted in half a glass of water. After an equilibration period of two hours, a venous plasma sample was taken. Plasma water was collected by sublimation in vacuo. $0.5 \mathrm{ml}$ of a colourless distillate was mixed with $10 \mathrm{ml}$ of scintillation liquid according to Moss $^{10}$ (200 g Naphtalene, $25 \mathrm{~g}$ PPO, $100 \mathrm{mg}$ POP in $2000 \mathrm{ml}$ Dioxane) and measured in a liquid scintillation counter (Tri-Carb, Packard Instrument Company). Total body water was calculated from the formula:

$$
\mathrm{TBW}=\frac{\text { total count of tritium adminstered }}{\text { counts/l of serum }}
$$

The total error of a total body water determination (the total expected standard deviation of a single determination) as calculated from a group of 20 women measured twice with about one month's interval was $\pm 1.031 .^{9}$

In order to investigate if patients with continent ileostomies have inadequate intestinal absorption of tritiated water we have studied five patients with continent ileostomies, where tritiated water was measured in the intestinal output collected during six hours after oral administration. The specific activity of tritiated water in the intestinal discharge was found to be the same as in plasma. Therefore ileal losses could be compared per millilitre with urinary losses during the equilibration period, resulting in a small and insignificant methodological error.

\section{Total body potassium}

This was determined by measuring the gamma radiation from the naturally present radionuclide ${ }^{40} \mathrm{~K}$, which is a constant fraction of all natural potassium, in a high sensitivity $3 \pi$ whole body counter containing four plastic scintillators with a total volume of $700 \mathrm{dm}^{3}$. The shielding consisted of a room made of a $15 \mathrm{~cm}$ thick iron ceiling and walls lined on the inside with $3 \mathrm{~mm}$ lead. The high sensitivity combined with the low background allows a count duration for each subject of only 100 seconds with a standard deviation of counting statistics of $\pm 50 \mathrm{mmol}$ ( 50 mequiv, $2.0 \mathrm{~g}$ ). The total expected standard deviation of a single potassium determination in adults was approximately \pm 80 mmol (80 mequiv, $3 \cdot 1 \mathrm{~g}){ }^{11}$

\section{Predicted values of total body potassium and total body water}

By means of multiple regression analyses of data from 476 healthy controls obtained in the same laboratory as in the present study, Bruce et $\mathrm{al}^{9}$ have shown that the normal values of total body potassium and total body water can be predicted by knowing the body weight, body height, and age of the subject. The following equations were derived: for males, TBK $=27.3 \mathrm{BW}+11.5 \mathrm{BH}-21.9 \mathrm{age}+778$ $(\mathrm{SE} \pm 314 \mathrm{mmol})$ and $\mathrm{TBW}=0.40 \mathrm{BW}+0.023$ $\mathrm{BH}-0.056$ age $+12 \cdot 1 \quad(\mathrm{SE} \pm 3.5$ 1). For females, $\mathrm{TBK}=16.7 \mathrm{BW}+16.7 \mathrm{BH}-7.9$ age $-821 \quad(\mathrm{SE} \pm 275$ $\mathrm{mmol}$ ) and $\mathrm{TBW}=0.24 \quad \mathrm{BW}+0.20 \quad \mathrm{BH}-0.03$ age $-13.9(\mathrm{SE} \pm 2.81)$.

In the present study we have also calculated predicted values of total body water from total body potassium by using a regression equation calculated from data obtained from the above-mentioned 476 controls, in order to compare our figures with those of Hill et al. ${ }^{4}$ The predicted values of total body water calculated in this way were: $\mathrm{TBW}=0.00846 \times \mathrm{TBK}+11 \cdot 10(\mathrm{SE} \pm 3 \cdot 6 \mathrm{l})$.

Electrolytes and creatinine values in serum were analysed in all patients. Urine was collected during a 24 hour period to determine the total volume and sodium and potassium losses.

\section{Results}

Table 2 shows the values of total body potassium and total body water together with the values of body weight and body height. In Table 3 the predicted and calculated values of total body potassium are compared for each patient. The

Table 2 Body weight (BW), body height $(B H)$, total body potassium. (TBK), and total body water $(T B W)$ in 14 patients with continent ileostomy

\begin{tabular}{lllll}
\hline $\begin{array}{l}\text { Patient } \\
\text { no. }\end{array}$ & $\begin{array}{l}B W \\
(\mathrm{~kg})\end{array}$ & $\begin{array}{l}\text { BH } \\
(\mathrm{cm})\end{array}$ & $\begin{array}{l}\text { TBK } \\
(\mathrm{mmol})^{*}\end{array}$ & $\begin{array}{l}\text { TBW } \\
(l)\end{array}$ \\
\hline 1 & $50 \cdot 0$ & 157 & 2330 & $28 \cdot 3$ \\
2 & $60 \cdot 3$ & 154 & 2700 & $28 \cdot 6$ \\
3 & $75 \cdot 0$ & 180 & 3660 & $44 \cdot 8$ \\
4 & $93 \cdot 0$ & 186 & 4380 & $52 \cdot 7$ \\
5 & $47 \cdot 0$ & 153 & 1970 & $25 \cdot 6$ \\
6 & $70 \cdot 9$ & 177 & 3760 & $43 \cdot 7$ \\
7 & $49 \cdot 8$ & 170 & 2590 & $30 \cdot 2$ \\
8 & $48 \cdot 0$ & 159 & 2040 & $23 \cdot 3$ \\
9 & $76 \cdot 7$ & 179 & 4290 & $48 \cdot 2$ \\
10 & $58 \cdot 0$ & 160 & 2590 & $31 \cdot 1$ \\
11 & $76 \cdot 5$ & 170 & 3700 & $43 \cdot 6$ \\
12 & $61 \cdot 6$ & 170 & 2870 & $34 \cdot 1$ \\
13 & $80 \cdot 0$ & 177 & 3740 & $43 \cdot 8$ \\
14 & 67.0 & 183 & 4020 & $45 \cdot 6$ \\
\hline
\end{tabular}

* $1 \mathrm{mmol} \mathrm{K}=1$ mequiv $\mathrm{K}=39 \cdot 1 \mathrm{mg} \mathrm{K}$. 
Table 3 Percentage deviation of calculated total body potassium (TBK) from predicted value of total body potassium $\left(P T B K^{*}\right)$ in 14 patients with continent ileostomy

\begin{tabular}{|c|c|c|}
\hline $\begin{array}{l}\text { Patient } \\
\text { no. }\end{array}$ & $\begin{array}{l}\text { PTBK } \dagger \\
(\mathrm{mmol})\end{array}$ & $\frac{T B K-P T B K}{P I B K} \times 100$ \\
\hline 1 & 2415 & $-3 \cdot 5$ \\
\hline 2 & 2323 & $16 \cdot 2$ \\
\hline 3 & 3844 & $-4 \cdot 8$ \\
\hline 4 & 4602 & $-4 \cdot 8$ \\
\hline 5 & 2085 & $-5 \cdot 5$ \\
\hline 6 & 3479 & $8 \cdot 1$ \\
\hline 7 & 2581 & 0.3 \\
\hline 8 & 2225 & $-8 \cdot 3$ \\
\hline 9 & 4054 & $5 \cdot 8$ \\
\hline 10 & 2393 & $8 \cdot 2$ \\
\hline 11 & 3880 & $-4 \cdot 6$ \\
\hline 12 & 2802 & $2 \cdot 4$ \\
\hline 13 & 4100 & -8.8 \\
\hline 14 & 4230 & $-5 \cdot 0$ \\
\hline \multicolumn{3}{|c|}{ Mean difference (\%): $-0 \cdot 3 \pm 2 \cdot 0($ SEM) } \\
\hline
\end{tabular}

* Calculated from the equations:

PTBK $=27 \cdot 3 \mathrm{BW}+11 \cdot 5 \mathrm{BH}-21.9 \mathrm{age}+778$ (males) and PTBK $=16 \cdot 7 \mathrm{BW}+16 \cdot 7 \mathrm{BH}-7 \cdot 9$ age -821 (females).

† $1 \mathrm{mmol} \mathrm{K}=1$ mequiv $\mathrm{K}=39 \cdot 1 \mathrm{mg} \mathrm{K}$.

difference between the measured value and the predicted value expressed in percentage of the predicted value varied between -8.8 and $+16.2 \%$ and the mean difference for all patients was $-0 \cdot 3 \pm 2 \cdot 0(\mathrm{SEM}) \%$.
In Table 4 the predicted and calculated figures of total body water are compared. The predicted values are computed in two different ways, described under 'Procedure'. When the predicted value of total body water was calculated from the values of body weight, body height, age, and sex, the percentage difference varied between -16.5 and $+8.8 \%$ (mean $-0.2 \pm 1.7$ (SEM) \%). When the predicted value was calculated from the values of total body potassium, the percentage difference varied between -18.0 and $+9.3 \%$ (mean $-3.0 \pm 2.1$ (SEM) \%). The differences between the calculated and predicted values of total body potassium and total body water are not statistically significant by either method of prediction.

Serum electrolytes were normal in all patients. Mean urinary sodium excretion was $54 \mathrm{mmol} / 24 \mathrm{~h}$ $(n=11$, range 24-107) and mean urinary potassium excretion was $72 \mathrm{mmol} / 24 \mathrm{~h}(\mathrm{n}=11$, range 33-110). All patients had a 24 hour urinary volume above 0.8 l except one, patient no. 8 , who only voided 0.34 $1 / 24 \mathrm{~h}$.

\section{Discussion}

In the present study total body potassium and total body water were measured in 14 patients with well-functioning continent ileostomies. The patients had had their continent ileostomy for at least six years and were in good general condition. The

Table 4 Percentage deviation of calculated total body water (TBW) from predicted value of total body water (PTBW*) in 14 patients with continent ileostomy

\begin{tabular}{|c|c|c|c|c|}
\hline \multirow[b]{2}{*}{$\begin{array}{l}\text { Patient } \\
\text { no. }\end{array}$} & \multicolumn{2}{|l|}{ Alt. 1} & \multicolumn{2}{|l|}{ Alt. 2} \\
\hline & $\begin{array}{l}P I B W \\
\text { (l) }\end{array}$ & $\frac{T B W-P T B W}{P T B W} \times 100$ & $\begin{array}{l}\text { PTBW } \\
\text { (l) }\end{array}$ & $\frac{T B W-P T B W}{P T B W} \times 100$ \\
\hline 1 & 28.7 & -1.4 & 30.8 & $-8 \cdot 1$ \\
\hline 2 & 29.7 & $-3 \cdot 7$ & 33.9 & $-15 \cdot 6$ \\
\hline 3 & 43.6 & $2 \cdot 8$ & $42 \cdot 1$ & 6.4 \\
\hline 4 & $51 \cdot 4$ & $2 \cdot 5$ & 48.2 & $9 \cdot 3$ \\
\hline 5 & $26 \cdot 3$ & $-2 \cdot 7$ & 27.8 & -7.9 \\
\hline 6 & $41 \cdot 3$ & 5.8 & 42.9 & 1.9 \\
\hline 7 & $31 \cdot 0$ & $-2 \cdot 6$ & 33.0 & $-8 \cdot 5$ \\
\hline 8 & 27.9 & $-16 \cdot 5$ & $28 \cdot 4$ & $-18 \cdot 0$ \\
\hline 9 & $44 \cdot 7$ & $7 \cdot 8$ & $47 \cdot 4$ & 1.7 \\
\hline 10 & 30.4 & $2 \cdot 3$ & 33.0 & $-5 \cdot 8$ \\
\hline 11 & $44 \cdot 2$ & $-1 \cdot 4$ & $42 \cdot 4$ & 2.8 \\
\hline 12 & 34.0 & $0 \cdot 3$ & $35 \cdot 4$ & $-3 \cdot 7$ \\
\hline 13 & $45 \cdot 9$ & $-4 \cdot 6$ & $42 \cdot 7$ & $2 \cdot 6$ \\
\hline 14 & 41.9 & $8 \cdot 8$ & $45 \cdot 1$ & $1 \cdot 1$ \\
\hline Mean difference $(\%)$ : & \multicolumn{2}{|c|}{$-0 \cdot 2 \pm 1 \cdot 7(\mathrm{SEM})$} & \multicolumn{2}{|c|}{$-3 \cdot 0 \pm 2 \cdot 1(\mathrm{SEM})$} \\
\hline
\end{tabular}

* Calculated from the equations:

alt. 1 PTBW $=0.40 \mathrm{BW}+0.023 \mathrm{BH}-0.056 \mathrm{age}+12.1$ (males). $\mathrm{PTBW}=0.24 \mathrm{BW}+0.20 \mathrm{BH}-0.03$ age -13.9 (females).

alt. 2 PTBW $=0.00846 \mathrm{TBK}+11 \cdot 1$. 
measured values of total body potassium and total body water were compared with values predicted from regression equations derived from 476 controls. Considerable variation from patient to patient of the difference between the measured values and the predicted values was noted. As a group, the patients with continent ileostomies, did not, however, significantly differ from normal.

Total body potassium reflects the total body cell mass and thus the nutritional state. The finding in the present study of a concordance between predicted and calculated values of total body potassium indicates that these patients had no protein malnutrition.

In the present investigation two alternative equations were used in predicting the 'normal' values of total body water for each patient. One was calculated by means of multiple regression analyses of total body water from body weight, body height, age, and sex, and the other by calculating total body water from total body potassium. In most patients only small differences between the two ways of calculating the predicted values were noted and both equations gave a standard error of the estimate around 3 litre. As both total body water and total body potassium are dependent on changes in body weight, body height, age, and sex, it is not surprising that the two ways of calculating give similar results. We prefer prediction of total body water calculated from weight, height, age, and sex, as it is a more direct method, but have alternatively used the prediction of total body water from total body potassium in order to be able to compare the present results with those obtained in patients with conventional ileostomies. ${ }^{4}$

Our results on total body water in patients with continent ileostomies contrast with those obtained by Clarke et $a l^{3}$ and Hill et $a l^{4}$ in patients with conventional ileostomies where a mean deficit in total body water of about $11 \%$ was found. From a hypothetical point of view, one possible explanation for a high total body water would be that patients with continent ileostomies could have an impaired absorption of tritiated water from the intestine, resulting in false low count of tritiated water in the plasma samples and thus an over-estimation of total body water. The results of measurements of tritiated water in the intestinal discharge showed, however, that the concentration of tritiated water in the intestinal contents was roughly the same as in the venous samples, thus indicating a good equilibration. Other possible explanations of the discrepancy in results are that patients with continent ileostomies have a better absorption of water, or that the differences are explained by the use of different control groups and different ways of predicting the 'normal' values of total body water. In the study of Clarke $e t l^{3}$ total body water was related only to body weight and in the study of Hill et $a l^{4}$ the predicted values were obtained from a control group consisting of only 22 male subjects. ${ }^{12}$ In our study we have calculated predicted values from multiple regression analysis based on sex, body weight, body height, and age. This should provide a more accurate prediction, as a positive correlation between these variables and total body water/total body potassium has been shown to exist. ${ }^{9}$ The finding of a mean urinary sodium excretion of about $55 \mathrm{mmol} / 24 \mathrm{~h}$ (55 mequiv, $2 \cdot 2 \mathrm{~g}$ ) suggests that sodium and water balance in these patients is normal.

In conclusion, the results of the present investigation indicate that patients with continent ileostomies do not have reduced total body water or total body mass compared with normal subjects. In order to investigate if there is any difference in total body water between patients with continent and conventional ileostomies examined in the same laboratory, a study of ileostomies before and after conversion from a conventional to a continent ileostomy is in progress.

This investigation was supported by grants from the Swedish Medical Research Council (project no. B 80-17X-00577-16C).

\section{References}

1 Smiddy FG, Gregory SD, Smith IB, Goligher JC. Faecal loss of fluid, electrolytes and nitrogen in colitis before and after ileostomy. Lancet 1960; 1: 14-19.

2 Gallagher ND, Harrison DD, Skyring AP. Fluid and electrolyte disturbances in patients with longestablished ileostomies. Gut 1962; 3: 219-23.

3 Clarke AM, Hill GL, Pope G, Stewart MK. Chronic dehydration and sodium depletion in patients with established ileostomies. Lancet 1967; 2: 740-3.

4 Hill GL, Goligher JC, Smith AH, Mair WSJ. Long term changes in total body water, total exchangeable sodium and total body potassium before and after ileostomy. Br J Surg 1975; 62: 524-7.

5 Kock NG. Intra-abdominal 'reservoir' in patients with permanent ileostomy. Arch Surg 1969; 99: 223-31.

6 Kock NG, Darle N, Hultén L, Kewenter J, Myrvold H, Philipson B. Ileostomy. Curr Probl Surg 1977; 14: 1-52.

7 Gadacz TR, Kelly KA, Phillips SF. The continent ileal pouch: absorptive and motor features. Gastroenterology 1977; 72: 1287-91. 
8 Nilsson LO, Andersson $\mathrm{H}$, Hultén L, Jagenburg R, Kock NG, Myrvold HE, Philipson B. Absorption studies in patients six to 10 years after construction of ileostomy reservoirs. Gut 1979; 20: 499-503.

9 Bruce $\AA$, Andersson M, Arvidson B, Isaksson B. Body composition. Prediction of normal body potassium, body water and body fat in adults on the basis of body height, body weight and age. Scand J Clin Lab Invest 1980; 40: 461-73.

10 Moss G. Scintillation counting of plasma tritiated water
(THO). J Lab Clin Med 1964; 63: 315-8.

11 Arvidsson B, Sköldborn H, Isaksson B. Clinical application of a high-sensitive whole-body counter. Third International Conference on Medical Physics, including medical engineering. Göteborg: Chalmers University of Technology, 1972; vol 41: 2 .

12 Hughes D, Williams RE, Smith AH. Clinical studies on whole-body potassium contents measured by gammaray spectrometry in health and disease. Clin Sci 1967; 32: 503-9. 